\title{
Effect of flushing of blastocysts on Days 10-13 on the life-span of the corpora lutea in the pig
}

\author{
J. van der Meulen, F. A. Helmond and C. P. J. Oudenaarden \\ Department of Animal Physiology, Agricultural University Wageningen, Haarweg 10, \\ 6709 PJ Wageningen, The Netherlands
}

\begin{abstract}
Summary. Blastocysts were flushed out of both uterine horns of gilts on Days 10,11, 12 or 13. In mated non-pregnant gilts flushing had no effect on progesterone profile or cycle length $(20.8 \pm 0.4$ versus $20.6 \pm 0.6$ days in the preflush cycle, $\mathrm{N}=6$, mean \pm s.e.m.). Flushing the blastocysts out of the uterine horns on Day 10 resulted in a cycle with a normal progesterone profile and a normal length $(21 \cdot 2 \pm 0.4$ days, $\mathrm{N}=5)$. Flushing on Days 11,12 or 13 resulted in a normal cycle or in maintenance of the CL for 3-13 days as indicated by elevated progesterone concentrations and an increased interoestrous interval of, respectively, 22.0 \pm 1.2 versus 19.8 \pm 0.6 days (Day 11; $\mathrm{N}=6$ ), $24 \cdot 8 \pm 1.4$ versus $21 \cdot 0 \pm 0.6$ days (Day $12 ; \mathrm{N}=5 ; P<0.05$ ) and $26.3 \pm 2.3$ versus $20.5 \pm 0.4$ days (Day $13 ; \mathrm{N}=6 ; P<0.05$ ). There was a positive relationship between the change in interoestrous interval and the interval between the first observed standing oestrus and flushing of the blastocysts $\left(r_{\mathrm{s}}=0.350 ; n=22 ; P<0 \cdot 1\right)$. There was a large variation in the diameter of the blastocysts flushed on the same day. Only in those gilts in which the blastocysts were $\geq 8 \mathrm{~mm}$ or filamentous were the CL maintained for 3 or more days. These results indicate that a first signal for maternal recognition of pregnancy is generated on Day 12 and that blastocysts $\geq 8 \mathrm{~mm}$ are required for prolongation of CL function for 3 or more days. Since CL function is only extended for a maximum of 13 days (mean $7 \cdot 4 \pm 1 \cdot 0$ ), a second signal seems necessary to maintain the CL for the whole period of pregnancy.
\end{abstract}

Keywords: CL; blastocysts; pregnancy; progesterone; pig

\section{Introduction}

The establishment and maintenance of pregnancy includes the exchange of signals between the developing conceptus and the maternal system. After fertilization and development to the blastocyst stage, the conceptus must provide a signal to bring about the maintenance of the corpora lutea $(\mathrm{CL})$ and the continuation of progesterone secretion. The prolongation of the functional life-span of the $\mathrm{CL}$ is a reflection of the maternal recognition of pregnancy which has occurred.

There is a critical period during which the blastocysts must provide the signal responsible for the maternal recognition of pregnancy. So far, this period has only been shown in experiments with unilaterally pregnant gilts. Removing blastocysts from one uterine horn on Day 12 or later does not disturb pregnancy in the other horn, whereas pregnancy is interrupted if blastocysts are flushed out of one horn on Day 4 or 10, i.e. blastocysts must be present in both uterine horns between Days 10 and 12 for continuation of pregnancy, while blastocysts need to be present in one horn only after Day 12 (Dhindsa \& Dziuk, 1968).

Other evidence about the time period in which the maternal recognition of pregnancy takes place involves administration of exogenous oestrogens, since oestrogens appear to provide the signal for the maternal recognition of pregnancy in the pig (Bazer \& Thatcher, 1977; see, for review, 
Bazer et al., 1984). Daily i.m. or intrauterine injections of oestradiol valerate or benzoate on Days 1 I-15 in non-pregnant gilts prolong luteal function for a variable time (Kraeling et al., 1975; Frank et al., 1977, 1978; Bazer et al., 1982; Ford et al., 1982b; Saunders et al., 1983; Ziecik et al., 1986; Geisert et al., 1987). One single i.m. injection of oestradiol benzoate between Days 9.5 and 14 results in maintenance of the CL for $\sim 7-10$ days (Kidder et al., 1955; Garverick et al., 1982; Geisert et al., 1987). However, no change in interoestrous interval occurs with administration before Day 9 or after Day 16 (Kidder et al., 1955; Geisert et al., 1987).

In this study the time of the maternal recognition of pregnancy was determined in a more direct way by flushing the blastocysts out of both uterine horns of pregnant gilts. It was investigated whether a relationship exists between the time of flushing or the blastocyst size and the life-span of the CL.

\section{Materials and Methods}

Animals and experimental design. Twenty-seven crossbred gilts (Great Yorkshire $\times$ Dutch Landrace) which had shown 2 or more normal oestrous cycles (18-22 days) were used. The gilts were checked for oestrus with a vasectomized boar twice daily $(09: 00$ and 15:00 h). At least 5 days before expected oestrus for the treatment cycle, they were fitted with an indwelling jugular vein catheter (PVC, $1.0 \mathrm{~mm}$ i.d., $1.5 \mathrm{~mm}$ o.d.). Blood samples were collected 3 times a day (09:00, 12:00 and 15:00 h). At the time of observing first standing oestrus (Day 0) $100 \mu \mathrm{g} \mathrm{GnRH}$ analogue (Ovalyse: Upjohn Company, Ede, The Netherlands) were injected i.m. and artificial insemination (AI) was carried out on Day 1, about $26 \mathrm{~h}$ after GnRH injection (van der Meulen et al., 1986). Blastocysts were flushed out of the uterine horns of the gilts at surgery on Day $10(\mathrm{~N}=5)$, Day $11(\mathrm{~N}=6)$, Day $12(\mathrm{~N}=5)$ or Day $13(\mathrm{~N}=6)$. Mated nonpregnant gilts were flushed on Days 10,11, 12 or 13 (Controls, $\mathrm{N}=5$ ). Blood sampling and checking for oestrus continued until slaughter 34 days after AI.

Surgery. The left uterine horn was exposed by lateral laparotomy under general anaesthesia with metomidateazaperone (Hypnodil-Stresnil: Janssen Pharmaceutica, Beerse, Belgium). The corpora lutea were marked with India ink to indicate at slaughter whether regression had taken place. A small incision was made just below the utero-tubal junction. A catheter was then passed through the incision into the uterine lumen and the cuff was inflated. A forceps was placed at the utero-cervical junction and a second catheter was placed just before this junction as described above. Through the first catheter $40 \mathrm{ml}$ sterile saline $(0.9 \% \mathrm{NaCl})$ were injected into the uterine lumen. Together with the fluid the blastocysts were forced by hand pressure towards the cervix and out through the second catheter into a sterile bottle. This was repeated with $20 \mathrm{ml}$ flushings until blastocysts were no longer in the flushings. After removing the catheters and suturing the incisions, the right uterine horn was treated in the same way. The blastocysts were measured and classified according to Pope \& First (1985).

Hormone analysis. All blood samples were collected into heparinized tubes and centrifuged; plasma was stored at $-20^{\circ} \mathrm{C}$ until further analysis.

Plasma concentrations of progesterone were measured in all samples by RIA (Helmond et al., 1980), using a specific rabbit antiserum against 4-pregnene-6 6 -ol-3,20-dione-hemisuccinate-BSA. The main cross-reacting steroids were pregnenolone $(98.0 \%)$, corticosterone $(2 \cdot 7 \%), 17 \alpha$-hydroxyprogesterone $(1.5 \%)$ and $20 \alpha$-hydroxy-4-pregnen-3one, cortisol, oestrone, oestradiol-17 $\beta$, oestradiol-17a, oestriol, androstenedione, dehydroandrosterone and testosterone (all $<0.2 \%)$. The antiserum was used in a final dilution of $1: 15000$. The sensitivity of the assay was $0.1 \mathrm{ng} / \mathrm{ml}$ at the $90 \% \mathrm{~B} / \mathrm{B}_{0}$ level. The intra-assay coefficient of variation was $7 \cdot 1 \%$ and the inter-assay coefficient of variation was $15.6 \%$.

Plasma concentrations of LH were measured in the samples collected around oestrus by a double-antibody RIA (Niswender et al., 1970), using pig LH (LER 786-3, potency $0.65 \times \mathrm{NIH-LH-S1)} \mathrm{as} \mathrm{a} \mathrm{standard} \mathrm{and} \mathrm{for} \mathrm{iodination.}$ Anti-ovine LH 614 IV was used at a 1:30000 working dilution and goat anti-rabbit immunoglobulin as the second antibody. The sensitivity of the assay was $0.7 \mathrm{ng} / \mathrm{ml}$ at the $90 \% \mathrm{~B} / \mathrm{B}_{0}$ level. The intra-assay coefficient of variation was $13 \cdot 8 \%$ and the inter-assay coefficient of variation was $14 \cdot 8 \%$.

Statistical analysis. The results for length of preflush and flush cycle were analysed by Student's paired $t$ test (twotailed). Spearman rank correlation coefficient was calculated between the time interval of the first observed standing heat and flushing on the one hand and the change in interoestrous interval on the other (Snedecor \& Cochran; 1980). All data are expressed as mean \pm s.e.m.

\section{Results}

In all five groups the highest $\mathrm{LH}$ concentrations were found $3 \mathrm{~h}$ after injecting the GnRH analogue. In all mated non-pregnant gilts and Day-10 flushed gilts, plasma progesterone concentrations 
declined to basal values between Days 15 and 18 (Fig. 1). In the other groups, plasma progesterone concentrations remained elevated after Day 18 in at least some gilts (Fig. 1). In one Day-13 flushed gilt, progesterone concentration did not decline until Day 30, but at slaughter on Day 35 the marked CL of this and all the other gilts had undergone regression. Compared with the duration of the preflush cycle (which did not differ for the 5 groups) the interoestrous interval of the gilts with extended luteal function had increased by $4-13$ days (mean $7 \cdot 4 \pm 1 \cdot 0, \mathrm{~N}=8$ ). This increase was significant for Day-12 flushing (21.0 \pm 0.6 versus $24.8 \pm 1.4$ days, $P<0.05)$ and Day-13 flushing (20.5 \pm 0.4 versus $26.3 \pm 2.3$ days, $P<0.05)$. Compared with flushing of mated non-pregnant gilts and Day-10 pregnant gilts the interoestrous interval after flushing on Day 11 was not significantly different, but after flushing on Day 12 and Day 13 the interoestrous interval was significantly longer (both $P<0.05$ ) (Table 1).

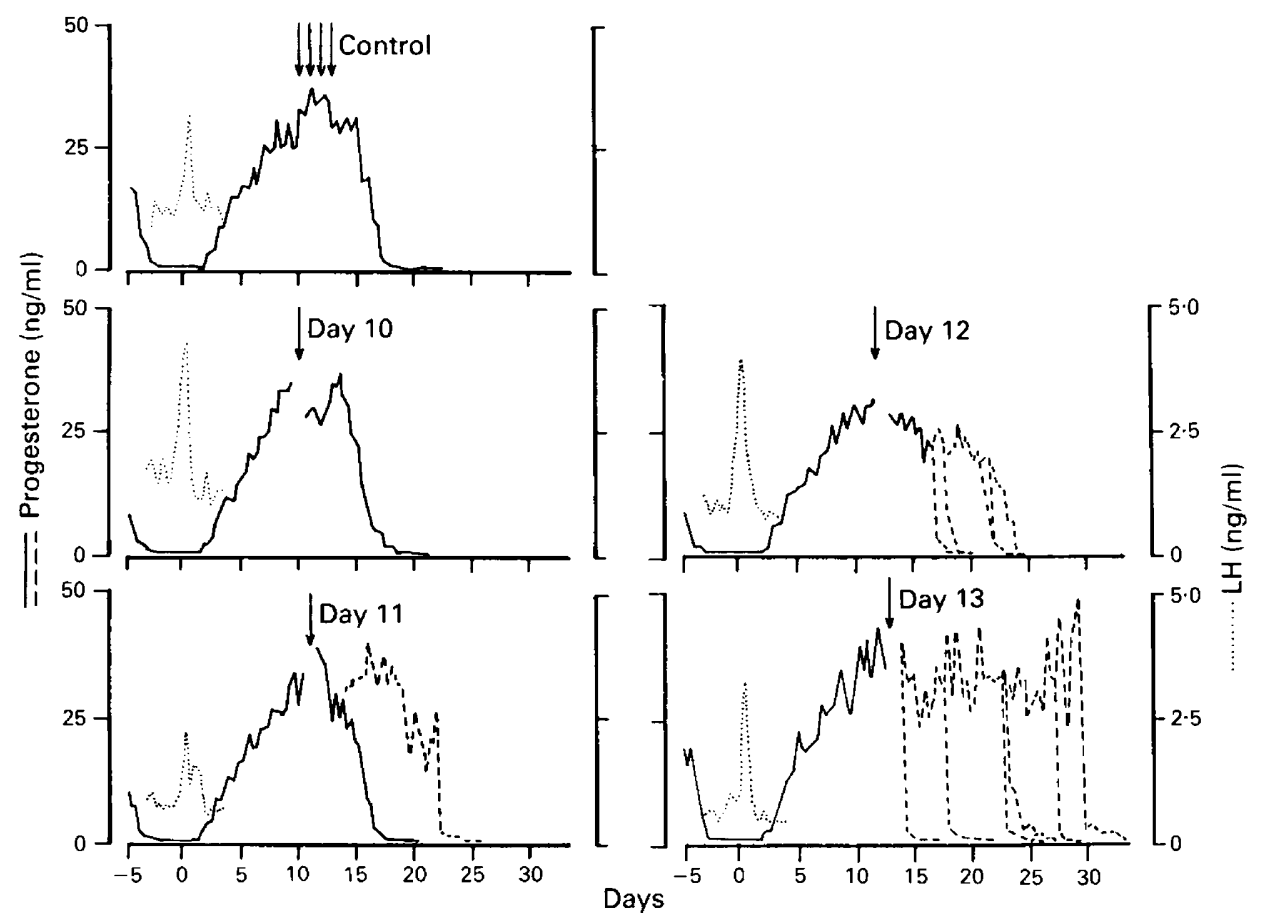

Fig. 1. The LH profile around oestrus and the progesterone profile before and after flushing until the next oestrus of mated non-pregnant gilts and gilts flushed (arrows) on Day 10,11, 12 and 13 . When progesterone concentrations did not return to basal values around Day 18 , the values for individual gilts are depicted (broken lines).

In the gilts in which flushing did not change the interoestrous interval for more than 3 days, the maximal blastocyst size varied from 0.5 to $6.9 \mathrm{~mm}$ in 11 gilts and in 3 gilts the blastocysts were filamentous. In the gilts with an increased interoestrous interval, after flushing of at least 3 days, the blastocysts were at least $8.0 \mathrm{~mm}$ or filamentous.

In all the gilts the time interval between the first observed standing heat and flushing ranged from 240 to $321 \mathrm{~h}$. There was a positive relationship between this time interval and the increase in the interoestrous interval $\left(r_{\mathrm{s}}=0 \cdot 350 ; n=22 ; P<0 \cdot 1\right)$.

\section{Discussion}

Since the cycle length may vary by about 2 days (Andersson \& Einarsson, 1980; own observations), an increase in the interoestrous interval of at least 3 days is considered as an extension of the CL 
Table 1. Interoestrous interval of preflush cycles and cycles when blastocysts were flushed from both uterine horns of gilts on different days

\begin{tabular}{lcccc}
\hline \multirow{2}{*}{$\begin{array}{l}\text { Day of } \\
\text { flushing }\end{array}$} & $\begin{array}{c}\text { No. of } \\
\text { gilts }\end{array}$ & \multicolumn{2}{c}{ Cycle length (days) } & $\begin{array}{c}\text { No. of gilts with } \\
\text { a change in cycle } \\
\text { length of }>3 \text { days }\end{array}$ \\
\hline Control & 5 & $20 \cdot 6 \pm 0 \cdot 6$ & Flush & $20 \cdot 8 \pm 0 \cdot 4$ \\
10 & 5 & $20 \cdot 6 \pm 0 \cdot 2$ & $21 \cdot 2 \pm 0 \cdot 4$ & 0 \\
11 & 6 & $19 \cdot 8 \pm 0 \cdot 6$ & $22 \cdot 0 \pm 1 \cdot 2$ & 1 \\
12 & 5 & $21 \cdot 0 \pm 0 \cdot 6^{\mathrm{a}}$ & $24 \cdot 8 \pm 1 \cdot 4^{\mathrm{b}}$ & 3 \\
13 & 6 & $20 \cdot 5 \pm 0 \cdot 4^{\mathrm{a}}$ & $26 \cdot 3 \pm 2 \cdot 3^{\mathrm{b}}$ & 4 \\
\hline
\end{tabular}

Values with different superscripts are different $(P<0 \cdot 05)$.

function. The results of this study show that blastocysts from Day 11 (just 1 of 6 gilts) or 12 signal their presence in such a way that an extension of the CL function occurs. The correlation between the time interval of the first observed standing heat and flushing on the one hand and the change in interoestrous interval on the other may indicate that the maternal recognition of pregnancy is a continuous process. Prolonged CL function, however, is only established in gilts with spherical blastocysts of $\geq 8 \mathrm{~mm}$ in diameter or filamentous blastocysts. The fact that large spherical blastocysts, just before elongation, already have the ability to prolong CL function finds support in studies concerning both the onset of the production of oestrogens and the presence of oestrogens in uterine flushings of pregnant animals. The conversion of androstenedione and dehydroepiandrosterone into both oestrone and oestradiol-17及, in vitro, is first detectable in spherical blastocysts of $5 \mathrm{~mm}$ (Perry et al., 1976) and the conversion of progesterone into oestradiol is initiated in blastocysts of $7 \mathrm{~mm}$ (Fischer et al., 1985). In pregnant sows, on Day 11 the concentration of oestrogens in uterine flushings is elevated, compared with unmated controls, only when the blastocysts are $>8 \mathrm{~mm}$ (Ford et al., 1982a). Blastocysts of this size also start to secrete low molecular weight acidic proteins, but the function of these proteins is not known (Godkin et al., 1982).

Blastocysts flushed out of both uterine horns on Days 11,12 or 13 had generated a signal by which the cycle length had increased on the average by 7.5 days with a maximum of 13 days. This indicates that the $\mathrm{CL}$, for the whole duration of pregnancy, require a prolonged signal or a second signal. The increase in cycle length after flushing is largely similar to the one after one intramuscular injection of oestradiol benzoate or diethylstilboestrol on Days $9 \cdot 5,11,12,12.5$ or 14 (Kidder et al., 1955; Garverick et al., 1982; Geisert et al., 1987). The existence of 2 signals is supported by the increase in interoestrous interval for $>60$ days after a single intramuscular injection of oestradiol benzoate on Day 11 followed by injections on Days 14-16 (Geisert et al., 1987). An increase in interoestrous length, after daily injections of oestradiol benzoate or valerate on Days 11-15, in a few cases to even more than 115 days (Kraeling et al., 1975; Frank et al., 1977, 1978; Bazer et al., 1982; Saunders et al., 1983; Ziecik et al., 1986; Geisert et al., 1987), may also indicate the existence of 2 signals, since intramuscular injection of oestradiol valerate results in elevated plasma oestrogen concentrations for several days after treatment (Geisert et al., 1982). Although oestrogens may account for both signals, the first signal is completed by Day 14 , as is indicated by a reduction of oestrogens in uterine flushings on Day 14 to non-pregnant levels (Geisert et al., 1982; Bazer et al., 1984; Stone \& Seamark, 1985). In pregnant gilts oestrogens in uterine flushings start to rise for the second time by Day 15 (Stone \& Seamark, 1985) and the second signal may occur around attachment (starting on about Day 16; King et al., 1982), the next crucial step in establishment of pregnancy after elongation (Morgan et al., 1987). Around Day 20, this second signal must have been completed, since intramuscular injection of oestradiol benzoate on Day 11 and on Days 20-22 results in a cycle of normal length in half of the gilts and in an increased interoestrous interval of about 60 days in the rest (Geisert et al., 1987). 
Glossop \& Foulkes (1988) provide further evidence to support our hypothesis of the existence of 2 signals. In their study $25 \cdot 6 \%$ of the sows returning to service did not do so by Day 21 but by Day $26 \cdot 5 \pm 2 \cdot 3$. This return to oestrus takes place almost at the same time as after flushing of blastocysts on Day 12 or 13 in this study. This indicates that these sows may have been pregnant around Day 13 (supported by the rosette inhibition titre in 2 sows, 2 weeks after mating, but returning to oestrus on Day 26; Morton et al., 1983), and that the blastocysts had been able to generate a first signal for the maternal recognition of pregnancy. In those sows the prolongation of the first signal or the generation of a second signal by the blastocysts seems to have been disturbed. Therefore, additional studies are needed to investigate the role of the 2 signals necessary for $C L$ maintenance for the whole duration of pregnancy in the pig.

We thank Dr L. E. Reichert for purified pig LH; Dr M. Ph. J. Hovius (Upjohn Company) for the GnRH analogue Ovalyse; Dr G. te Kronnie, Mr M. Graat, Mr W. van Straalen, Mr T. Schneidenberg and Mrs J. de Leeuw for technical assistance; Mr J. van Brakel for preparing the illustrations; and Mrs T. van Bemmel for typing the manuscript. This research was partly supported by the LEB fund. This work was carried out within the framework of the working Party on Early Pregnancy at the Agricultural University.

\section{References}

Andersson, A.M. \& Einarsson, S. (1980) Studies on the oestrus and ovarian activity during five successive oestrous cycles in gilts. Acta vet. scand. 21, 677-688.

Bazer, F.W. \& Thatcher, W.W. (1977) Theory of maternal recognition of pregnancy in swine based on estrogen controlled endocrine versus exocrine secretion of prostaglandin $\mathrm{F} 2 \alpha$ by the uterine endometrium. Prostaglandins 14, 397-401.

Bazer, F.W., Geisert, R.D., Thatcher, W.W. \& Roberts, R.M. (1982) The establishment and maintenance of pregnancy. In Control of Pig Reproduction, pp. 227-252. Eds D. J. A. Cole \& G. R. Foxcroft. Butterworths, London.

Bazer, F.W., Marengo, S.R., Geisert, R.D. \& Thatcher, W.W. (1984) Exocrine versus endocrine secretion of prostaglandin $\mathrm{F} 2 \alpha$ in the control of pregnancy in swine. Anim. Reprod. Sci. 7, 115-132.

Dhindsa, D.S. \& Dziuk, P.J. (1968) Effect of pregnancy in the pig after killing embryos or fetuses in one uterine horn in early gestation. J. Anim. Sci. 27, 122-126.

Fischer, H.E., Bazer, F.W. \& Fields, M.J. (1985) Steroid metabolism by endometrial and conceptus tissues during early pregnancy and pseudopregnancy in gilts. J. Reprod. Fert. 75, 69-78.

Ford, S.P., Christenson, R.K. \& Ford, J.J. (1982a) Uterine blood flow and uterine arterial, venous and luminal concentrations of oestrogens on Days 11, 13 and 15 after oestrus in pregnant and non-pregnant sows. J. Reprod. Fert. 64, 185-190.

Ford, S.P., Magness, R.R., Farley, D.B. \& Van Orden, D.E. (1982b) Local and systemic effects of intrauterine estradiol-17 $\beta$ on luteal function of nonpregnant sows. J. Anim. Sci. 55, 657-664.

Frank, M., Bazer, F.W., Thatcher, W.W. \& Wilcox, C.J. (1977) A study of prostaglandin $\mathrm{F} 2 \alpha$ as the luteolysin in swine. III. Effects of estradiol valerate on prostaglandin $F$, progestins, estrone and estradiol concentrations in the utero-ovarian vein of nonpregnant gilts. Prostaglandins 14, 1183-1196.
Frank, M., Bazer, F.W., Thatcher, W.W. \& Wilcox, C.J. (1978) A study of prostaglandin F2 $\alpha$ as the luteolysin in swine. IV. An explanation for the luteotrophic effect of estradiol. Prostaglandins 15, $151-160$.

Garverick, H.A., Polge, C. \& Flint, A.P.F. (1982) Oestradiol administration raises luteal $\mathrm{LH}$ receptor levels in intact and hysterectomized pigs. J. Reprod. Fert. 66, $371-377$.

Geisert, R.D., Renegar, R.H., Thatcher, W.W., Roberts, R.M. \& Bazer, F.W. (1982) Establishment of pregnancy in the pig: I Interrelationships between preimplantation development of the pig blastocyst and uterine endometrial secretions. Biol. Reprod. 27, 925-939.

Geisert, R.D., Zavy, M.T., Wettemann, R.P. \& Biggers, B.G. (1987) Length of pseudopregnancy and pattern of uterine protein release as influenced by time and duration of oestrogen administration in the pig. $J$. Reprod. Fert. 79, 163-172.

Glossop, C.E. \& Foulkes, J.A. (1988) Occurrence of two phases of return to oestrus in sows on commercial units. Vet. Rec. 122, 163-164.

Godkin, J.D., Bazer, F.W., Lewis, G.S., Geisert, R.D. \& Roberts, R.M. (1982) Synthesis and release of polypeptides by pig conceptuses during the period of blastocyst elongation and attachment. Biol Reprod. 27, 977-987.

Helmond, F.A., Simons, P.A. \& Hein, P.R. (1980) The effect of progesterone on estrogen-induced luteinizing hormone and follicle-stimulating hormone release in the female rhesus monkey. Endocrinology 107, $478-485$.

Kidder, H.E., Casida, L.E. \& Grummer, R.H. (1955) Some effects of estrogen injections on the estrual cycle of gilts. J. Anim. Sci. 12, 470-474.

King, G.J., Atkinson, B.A. \& Robertson, H.A. (1982) Implantation and early placentation in domestic ungulates. J. Reprod. Fert., Suppl. 31, 17-30. 
Kraeling, R.R., Barb, C.R. \& Davis, B.J. (1975) Prostaglandin-induced regression of porcine corpora lutea maintained by estrogen. Prostaglandins 9, $459-462$.

Morgan, G.L., Geisert, R.D., Zavy, M.T. \& Fazleabas, A.T. (1987) Development and survival of pig blastocysts after oestrogen administration on Day 9 or Days 9 and 10 of pregnancy. J. Reprod. Fert. 80, 133-141.

Morton, H., Morton, D.J. \& Ellendorfi, F. (1983) The appearance and characteristics of early pregnancy factor in the pig. J. Reprod. Fert. 68, 437-446.

Niswender, G.D., Reichert, L.E. \& Zimmerman, D.R. (1970) Radioimmunoassay of serum levels of luteinizing hormone throughout the estrous cycle in pigs. Endocrinology 87, 576-580.

Perry, J.S., Heap, R.B., Burton, R.D. \& Gadsby, J.E. (1976) Endocrinology of the blastocyst and its role in the establishment of pregnancy. J. Reprod. Fert., Suppl. 25, 85-104.

Pope, W.F. \& First, N.L. (1985) Factors affecting the survival of pig embryos. Theriogenology 23, 91-105.

Saunders, M.J., Edgerton, L.A., Kagan, J.M., Stahly, T.S. \& Cromwell, G.L. (1983) Comparison of intrauterine and subcutaneous sites of estrogen injection for luteal maintenance in swine. J. Anim. Sci. 57, 146-149.

Snedecor, G.W. \& Cochran, W.G. (1980) Statistical methods. The Iowa State University Press, Ames, Iowa.

Stone, B.A. \& Seamark, R.F. (1985) Steroid hormones in uterine washings and in plasma of gilts between Days 9 and 15 after oestrus and between Days 9 and 15 after coitus. J. Reprod. Fert. 75, 209-221.

van der Meulen, J., Helmond, F.A., Hovius, M.Ph.J., Van Haastrecht, J., Graat, M., Nutma, A., Van Straalen, W. \& Oudenaarden, C. (1986) Synchronization of the preovulatory LH peak with the onset of behavioural oestrus in cyclic gilts by an LHRH analogue. Proc. 9th Congr. IPVS, Barcelona, 59, Abstr.

Ziecik, A., Doboszynska, T. \& Dusza, L. (1986) Concentrations of $\mathrm{LH}$, prolactin and progesterone in early pregnant and oestradiol-treated pigs. Anim. Reprod. Sci. 10, 215-224. 